\title{
REFINED COASTAL MODELING AND ENGINEERING ANALYSIS FOR THE WRIGHTSVILLE BEACH COASTAL STORM DAMAGE REDUCTION PROJECT
}

\author{
Zhanxian Wang, Moffatt \& Nichol, zwang@moffattnichol.com \\ Nicole Vanderbeke, Moffatt \& Nichol, nvanderbeke@moffattnichol.com \\ Brandon Grant, Moffatt \& Nichol, bgrant@moffattnichol.com \\ Layton Bedsole, New Hanover County, lbedsole@nhcgov.com
}

\begin{abstract}
INTRODUCTION
In an effort to enhance the Coastal Storm Damage Reduction (CSDR) project at Wrightsville Beach (WB), NC, New Hanover County authorized a refined coastal modeling study in partnership with the Town of Wrightsville Beach. The purpose of the modeling analysis includes the review of potential design betterments that may increase the project's storm protection benefits.
\end{abstract}

\section{METHODOLOGY}

The refined modeling analysis evaluates the anticipated longshore transport and cross-shore storm impacts associated with multiple construction templates to estimate potential project improvements. The analysis utilizes a set of state-of-art coastal engineering modeling platforms including GenCade (Frey et al, 2012), Delft3D (Deltares, 2016), and SBEACH (Larson and Kraus, 1989) to evaluate the respective shoreline evolution, longshore transport, morphological change, and cross-shore storm impacts. The GenCade model is used to estimate the shoreline position, while the Delft3D model aids in estimating the annual volumetric change for each alternative. The SBEACH numeric model provides the assistance necessary for the cross-shore storm impacts analysis.

\section{MODEL CALIBRATIONS}

The model calibration serves an integral part of any numeric analysis. The calibration process helps to verify that the modeling simulations could reasonably replicate real world results within an acceptable level of accuracy. Figure 1 to Figure 3 show the calibration results at Wrightsville Beach for GenCade, Delft3D, and SBEACH, respectively.

\section{ALTERNATIVES ANALYSIS}

Analysis of potential project alternatives includes five (5) template designs as referenced below. Alternative 1 corresponds to the existing USACE design template. The analysis evaluates each alternative in terms of the shoreline change, longshore transport and volumetric change expected along with the estimated storm protection available during the projects design life.

- $\quad$ Alternative 1 - USACE (WB9.5 - WB16.5)

- Alternative 2 - Extended (WB7.5 - WB16.5)

- Alternative 3 - 65/35 (WB7.5 - WB16.5)

- $\quad$ Alternative 4 - Thin (WB4.5 - WB20.5)

- Alternative 5 - 55/45 (WB7.5 - WB16.5)

The SBEACH modeling analysis shows that Alternative 5 provides the most likely opportunity for increasing the storm protection potential for northern Wrightsville Beach, while maintaining the historic level of benefit for southern Wrightsville Beach. The GenCade analysis shows Alternative 5 retains the largest shoreline advance along the southern region of Wrightsville Beach with the exception of Alternative 1. However, Alternative 5 provides a significant seaward advance of the northern shoreline near WB09, where Alternative 1 only provides a transitional material placement. The Delft3D analysis also estimates Alternatives $3 \& 5$ would improve the CSDR project performance. The analysis suggests both referenced alternatives hold the greatest potential to retain material volume in the out-year construction period.

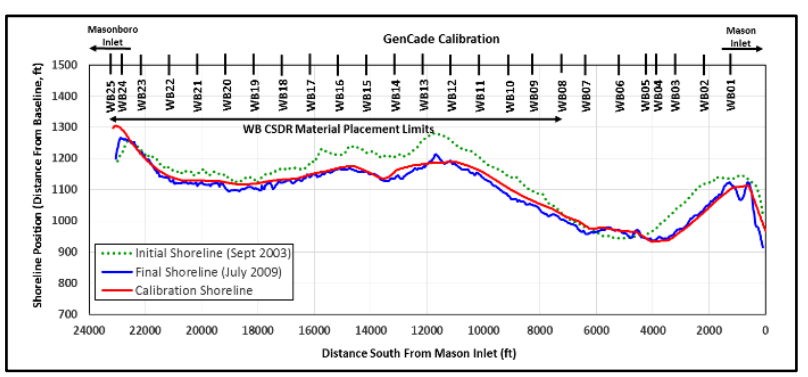

Figure 1 - GenCade calibration results

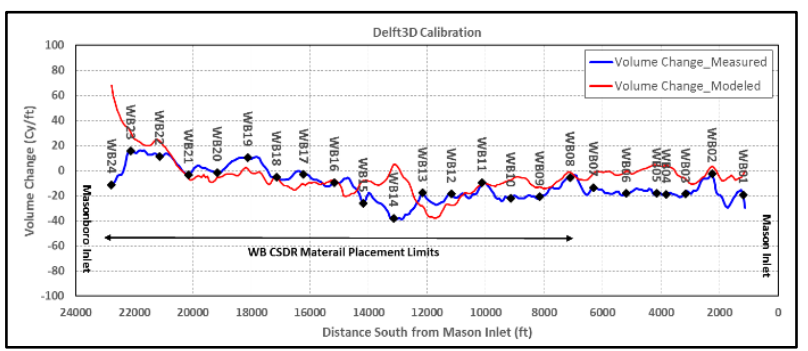

Figure 2 - Delft3D calibration results

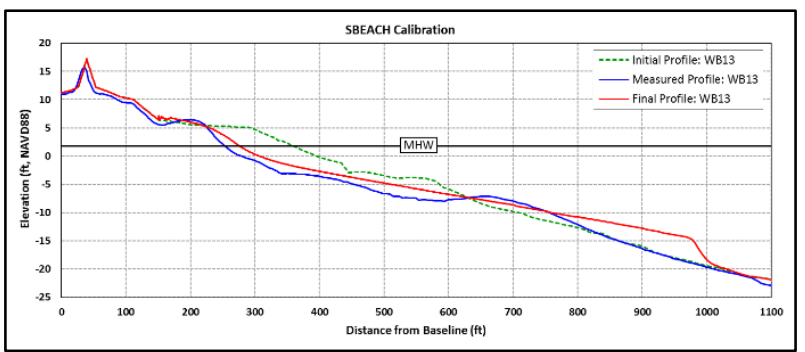

Figure 3 - SBEACH calibration results

\section{REFERENCES}

Deltares (2016): Delft3D-FLOW User Manual, Deltares.

Frey, A.E., Connell, K.J., Hanson, H., Larson, M., Thomas, R.C., Munger, S., and Zundel, A. (2012): GenCade Version 1 Model Theory and User's Guide, ERDC-CHL-TR-12-25, USACE Coastal and Hydraulics Laboratory, Engineer Research and Development Center, Vicksburg.

Larson, M. and Kraus, N.C. (1989): SBEACH: Numerical Model for Simulating Storm-induced Beach Change; Report 1: Empirical Foundation and Model Development, CERC-899, USACE Coastal Engineering Research Center, Vicksburg. 